\title{
POTENSI DIRI dan GAMBAR-RUPA ALLAH
}

Oleh: Edward E. Hanock

\begin{abstract}
Abstrak
Teologi Kristen memandang manusia adalah ciptaan Allah yang segambar-serupa dengan-Nya

(bnd. Kej. 1-2). Implikasi dari pandangan ini berdampak cukup luas. Bukan saja pada pewarisan sifat-sifat-Nya, melainkan juga pada pertanyaan serius, apakah potensi diri manusia itu terdapat dalam gambar-rupa Allah yang dimiliki manusia tersebut? Untuk menelisik lebih

jauh keberadaan potensi diri manusia dalam perspektif teologi, maka penelitian ini akan menggunakan pendekatan kepustakaan. Informasi-informasi dari sejumlah literatur, termasuk beberapa bagian Alkitab, akan dikaji guna menjawab pertanyaan di atas.

Hasil dari penelitian ini menggambarkan bahwa manusia benar-benar memiliki potensi yang unggul, yang secara tidak langsung terdapat di dalam dirinya sebagai pemilik gambar-rupa Allah.
\end{abstract}

Kata kunci: potensi, gambar-rupa, diri.

\section{PENDAHULUAN}

Tidak bisa disangkal lagi bahwa dunia (baca: zaman) di mana kita tinggali sekarang terus menunjukkan kemajuan peradaban dan teknologi yang sangat cepat. Perubahan itu seolah-olah sulit kita ikuti. Karena selalu saja ada kejutan-kejutan yang di berbagai bidang. Paling banyak terjadi di dunia teknologi. Alih-alih kita berhenti sejenak, kita pun sepertinya dipaksa untuk bersiap melihat hal-hal baru dari teknologi. Mengapa demikian? Karena $R \mathcal{E} D$ (research and development) terus dilakukan dengan total investasi miliaran dolar. ${ }^{1}$ Tidak mengherankan jika di kemudian hari teknologi yang dihasilkan semakin mutakhir.

Diskursus tentang perkembangan

'Salah satu raksasa teknologi Tiongkok dengan total investasi R\&D yang besar adalah Huawei. Seperti dikutip dari https://inet.detik.com/consumer/d4192214/untuk-apa-saja-dana-riset-miliaran- teknologi itu lalu dihubungkan dengan perubahan zaman, yang disebut sebagai era generasi post-millennial. Pada zaman mereka, di mana generasi-generasi sebelumnya juga menjadi bagian di dalamnya, teknologi dengan segala turunannya bukan hal yang mengejutkan. Demikian halnya dengan koneksi internet, karena hal tersebut bukan lagi menjadi isu utama, walaupun ada Internet of Thing (IoT). Yang sedang popular adalah Artificial Intelligence (AI)/kecerdasan buatan, Blockchain (berkas berantai), Cryptocurrency (mata uang Kripto: Bitcoin, Libra), post-truth, dan [era] disrupsi, serta masih banyak hal lain sudah mulai familiar di dunia kita.

Dengan kemajuan teknologi dewasa ini, sebagaimana tergambar dari

dolar-huawei/komentar? device $=$ desktop (diakses pada 15 November 2019), raksasa teknologi itu dikabarkan menghabiskan 15-20 milliar Amerika Serikat atau setara dengan 219-292 triliun rupiah. 
beberapa istilah di atas, patutlah sorotan kita dialihkan kepada manusia itu sendiri, sebagai konseptor dan kreator ulung dan bukan kepada benda-benda mutakhir yang dihasilkannya. Karena dalam konteks ini, manusia telah menunjukan pencapaian diri dengan segala potensinya yang begitu mengagumkan. Potensi itu akan terus berkembang menuju titik puncak berikutnya, sebelum ia kemudian menetapkan pencapaian lain yang lebih hebat dari sebelumnya.

Dengan menyinggung konsep 'diri' dan 'potensi' manusia, dalam pengertian kecerdasan dan kemampuannya untuk mengonsep dan mencipta sesuatu, maka saya ingin melakukan penelusuran dari berbagai sudut pandang keilmuan terhadap manusia itu sendiri dan kemudian saya korelasikan dengan perspektif biblis guna menjawab pertanyaan apakah potensi manusia terbingkai dalam gambar-rupa Allah sehingga secara otomatis ia tinggal diasah hingga menjadi lebih meningkat dari sebelumnya. Atau, apakah potensi tersebut merupakan sebuah kemampuan 'bawaan' yang dapat berkembang sesuai dengan kemapuan manusia dalam mengusahakannya; dan apakah potensi tersebut adalah gift dan talent (pemberian) Allah yang dimiliki oleh semua orang, sekalipun setiap orang tidak memilikinya secara sama.

Selain isu di atas, secara sepintas akan disinggung juga soal dampak atau pengaruh teknologi dalam peradaban manusia. Hal ini merupakan tantangan terbesar bagi manusia. Apakah manusia hanya mampu menghasilkan perangkat-perangkat teknologi yang mutakhir, tanpa berhasil sedikitpun mengurangi penyalahgunaannya? Yang dimaksud di sini adalah soal etika (etis) seseorang, yakni bagaimana ia harus bersikap secara tepat dan benar terhadap kemampuan potensi diri manusia. Karena ibarat sebuah koin dengan 2 (dua) sisi, potensi diri manusia itu dapat melebur ke dalam hal-hal yang konstruktif dan destruktif.

Sorotan yang paling tajam seringkali diarahkan pada hal-hal destruktif yang secara kasat mata tampak dengan jelas di sekitar kita, tanpa bermaksud sedikitpun mengabaikan hal-hal monumental (positif) lainnya. Misalnya: cyber crime (kejahatan di dunia maya). Memang sudah sepatutnya hal-hal yang merugikan manusia itu disoroti secara bijak dan kritis, sambil memberikan solusi yang bermanfaat. Bila sikap kritis ini diacuhkan dan tidak segera menawarkan cara-cara bersikap, maka bisa saja potensi diri manusia akan menjadi bom waktu, yang dapat melululantakan peradaban manusia itu sendiri. Tidak dimaksudkan di sini untuk mendikotomikan potensi diri manusia. Atau, dalam arti yang lebih konkrit, menghadap-hadapkan dua kelompok orang dengan potensi diri yang baik dan jahat. Kelompok yang satu terus-menerus mengembangkan diri dan potensi mereka untuk tujuan tertentu, dan vice versa.

Agar tidak meluas, beberapa pertanyaan berikut ini berikut ini bisa mempertajam artikel ini. Pertama, apakah konsep gambar-rupa Allah memberi andil dalam potensi diri 
manusia, berikut upaya pengembangannya? Kedua, apakah potensi diri itu terkait dengan skill (keterampilan) atau virtue (kebajikan)? Ketiga, sejauh mana potensi diri itu sendiri mengeliminasi hal-hal yang bersifat eksesif yang diprediksi akan muncul dari potensi diri manusia tersebut?

\section{METODOLOGI PENELITIAN}

Secara metodologis, penelitian ini akan menggunakan metode kualitatif melalui pendekatan studi kepustakaan. Dengan demikian buku, jurnal (cetak dan online), dan beberapa nas Kitab Suci (PL/PB) merupakan sumber data yang sangat berperan penting di sini. Dari sumber-sumber tersebut, data dan informasi akan dikumpulkan dan dikaji kembali. Hasil dari kajian itu akan disimpulkan dalam sebuah catatan akhir dari artikel ini.

\section{PEMBAHASAN}

\section{Diri dan Potensi atau Potensi} Diri? Pertanyaan pengantar pada pembahasan artikel Potensi Diri dan Gambar-Rupa Allah adalah apakah ada kesamaan antara pengembangan potensi diri dan pengembangan diri? Analoginya sebagai berikut: potensi dalam intensi topik ini merujuk pada isi, sedangkan 'diri' tidak lain menunjuk pada wadah atau tempat. Atau dalam dugaan berikut: potensi menerangkan diri dan bukan sebaliknya. Secara sederhana, kedua analogi di atas menerangkan bahwa potensi lebih penting dari diri. Dengan mengatakannya demikian, maka tentu diperlukan keberanian dengan dasar pijak yang solid. Karena potensi lebih bersifat abstrak, sedangkan diri lebih konkret. Ibarat sebuah susunan warna, yang sebenarnya terdiri atas susunan pixel yang tersusun sangan solid sehingga terlihat sebagai warna yang indah. Dalam konteks psikologi, gagasan-gagasan di atas menjadi lebih kompleks. Diri pun dideskripsi sedemikian rupa, sehingga cenderung memiliki arti yang abstrak.

Dugaan selanjutnya bertolak dari keutamaan diri, baru disusul oleh potensi. Artinya, diri manusia sebenarnya bisa terlihat lebih dari sekadar hari ini dan di sini. Ia bisa terlihat berbeda pada masa yang akan datang (dan di tempat yang berbeda). Diri seseorang tidak bisa dilimitasi oleh unsur tempus (waktu) dan locus (tempat). Ia akan berkembang dan terlihat lebih cerdas, berhikmat, terlatih, dan berpengaruh. Titik tolak penilaian pertama adalah diri secara keseluruhan. Baru kemudian dilihat lebih spesifik. Salah satunya adalah menelisik potensinya. Sejauh mana potensi itu distimulans dan diberikan dorongan untuk lebih berani bereksperimen. Seseorang (baca: diri) membutuhkan sebuah tantangan untuk menjadi sarana eksplorasi diri baginya. Dengan demikian seseorang dapat melihat gambaran diri yang lebih aktual karena upaya-upaya pengembangan potensi itu.

Pada tataran permukaan, menurut hemat saya, 'diri' adalah subjek 
sedangkan 'potensi' - dalam hal ini sebagai bagian yang tidak bisa dipisahkan dari manusia — adalah objek yang teraktualisasi secara memadai dan proporsional. Tentu ada fase di mana keduanya dapat diterangkan secara terpisah sekalipun perlu disadari di sini juga bahwa pada dasarnya sulit memisahkan secara kasat mata, mana ekspresi diri dan mana aktualisasi potensi. Karena keduanya telah melebur menjadi satu. Selain itu, mata kita hanya menangkap objek yang kelihatan terlebih dahulu (positivistik), baru ditransfer dan detail dari objek tadi diolah oleh pikiran kita. Di sini tidak berarti bahwa menggambarkan diri harus dimulai dari hal-hal yang abstrak.

Sejauh ini, kedua kemungkinan di atas, yakni: diri-potensi dan potensidiri dapat dikoreksi sebagai berikut. Bahwa diri-potensi bukanlah sebuah formulasi terminologi yang mudah dimengerti dan belum tentu pas, karena formulasi ini lebih terlihat asing atau janggal. Lebih cocok jika diformulasikan sebagai diri dan potensi. Sebaliknya, potensi diri sudah lazim dikenal di dalam diskursus psikologi. Potensi adalah 'sesuatu' yang terpendam dan bisa berkembang jika potensi-potensi itu mendapat perhatian dan dorongan baik dari dalam diri sendiri (internal) maupun dari luar diri (eksternal).

Seseorang tidak dapat membahas

2 Lih. Albert Bandura, Self Efficacy. The Exercise of Control (New York: W.H. Freeman and Company, 1997). potensi terlepas dari diri, dan atau sebaliknya. Apakah dengan demikian dapat dikatakan bahwa potensi yang dalam beberapa hal tampak melalui tindakan seseorang adalah gambaran diri yang utuh dari orang tersebut? Tentu saja, tidak semudah itu. Potensi merupakan mozaik kecil yang dapat menggambarkan lukisan diri seseorang yang besar, agung, dan mulia. Jika potensi diri seseorang tidak dikembangkan, apalagi tidak teraktualisasi, maka hal itu tidak mengurangi hakikatnya sebagai manusia. Justru yang menggelitik adalah jika ia—sebagai manusia—tidak mempunyai dorongan dari dalam untuk menggunakan semua potensinya sebagai upaya konkret menuju pengembangan diri. I Made Rustika, dalam tinjauannya terhadap teori efikasi diri [psikologi] yang dikembangkan oleh Albert Bandura, ${ }^{2}$ menghubungkan potensi diri dengan teori efikasi diri. Efikasi diri itu berkaitan erat dengan konsep diri, harga diri, dan kendali diri. Artinya, diri dan potensi selalu bersama dan mewujudnyata dalam diri seseorang. ${ }^{3}$

\section{DIRI}

Secara filosofis, Ludwig Wittgenstein dalam Tractatus LogicoPhilosophicus mengaitkan konsep diri sebagai bagian dari fakta solipsisme ${ }^{4}$ yang

${ }^{3}$ I Made Rustika, "Efikasi Diri: Tinjauan Teori Albert Bandura" dalam Buletin Psikologi, vol. 20, No.1-2 (2012), 18.

${ }^{4}$ Solipsisme adalah teori yang menyatakan bahwa diri adalah semua yang dapat diketahui 
terjadi bersamaan dengan realisme ${ }^{5}$ murni. ${ }^{6}$ Artinya, fakta itu menyusut ke satu titik tanpa ada perluasan. Wittgenstein tidak mengaitkan pembahasan tentang 'diri' dalam ruang percakapan menurut cara-cara psikologis, melainkan filosofis. Diri, baginya, lebih ideal didiskusikan secara filosofis karena anggapan dunia adalah dunia saya. Anggapa ini menyeret batas diri pada batas dunia. Bagi Wittgenstein diri secara filosofis tidak menyentuh aspek keberadaan, tubuh, jiwa manusia sebagaimana menjadi perhatian dari psikologi. Diri, dalam sudut pandang filsafat terkait dengan pokok metafisis yang bukan bagian dari dunia. $^{7}$

Rollo May patut juga mendapat perhatian karena ia, menurut Vitz, ${ }^{8}$ merupakan contoh dari potret yang kuat dari pengaruh filsafat eksistensial terhadap psikologi diri. ${ }^{9}$ Jika Wittgenstein menekankan das ich, maka May memiliki perspektif berbeda. Ia menekankan dasein ('being there', berada di sana). Maksudnya adalah sebuah gagasan yang menerangkan tentang kesadaran fundamental secara konstan akan keberadaan seseorang, secara khusus di dalam dunia ini. 'Di sana' bukan berarti transenden dan

berada. KBBI mendefinisikan Solipsisme sebagai teori bahwa satu-satunua pengetahuan yang mungkin adalah pengetahuan tentang diri sendiri.

${ }^{5}$ Realisme adalah ajaran/paham yang selalu bertolak dari kenyataan (KBBI). Dalam Oxford Dictionary dikatakan sebagai doktrin bahwa konsep-konsep universal atau abstrak memiliki sebuah keberadaan (eksistensi) objektif dan absolut.

6 Ludwig Wittgenstein, Tractatus Logico Philosophicus, ${ }^{2}$ terj. D.F. Pears dan B.F. beyond (di luar jangkauan), melainkan di dekat bahkan menjadi bagian yang tidak terpisahkan dengan dunia. Ada 3 (tiga) ciri bagaimana seseorang mengekspresikan keberadaannya: umwelt (dunia sekitar), mitwelt (dunia dengan $[\ldots]$ ), dan eigenwelt (dunia seseorang). Dengkan kata lain, seseorang selalu punya kesempatan untuk berada di dunia sekitar untuk membaurkan dirinya di dalam dunia itu, meskipun ia selalu terlihat protektif terhadap dunianya sendiri.

Terkait dengan pengembangan potensi diri, maka yang penting ialah soal becoming (menjadi). Vitz mengatakan bahwa proses pengembangan diri atau pemenuhan potensi bertolak dari eksistensial individu 'aku ada' tersebut.

Steve Andreas menaruh perhatian pada soal self (diri). Bukunya cukup provokatif: Transforming Your Self: Becoming Who You Want to Be (terj. bebas: Mentransformasi Diri Sendiri: Menjadi yang Anda Inginkan Terjadi). Sebagai catatan awal, Steve Andreas mengelaborasi beberapa istilah yang lazim digunakan ketika membicarakan atau mendiskusikan tentang diri sendiri, seperti: diri (self), gambar-diri (self-image), dan identitas (identity). ${ }^{10}$ Walaupun sudah membahas panjang

MacGuinnes, (London/New York: Roudledge, 1974), 64.

${ }^{7}$ Ibid., 70.

8 Paul C. Vitz, Psikologi sebagai Agama: Kultus Penyembahan Diri, terj. Yulvita Hadiyarti, (Surabaya: Penerbit Momentum, 2005), h. 15

${ }_{9}$ Rollo May, Existence (New York: Basic Books), 3-36.

10 Steve Andreas, Transforming Your Self: Becoming Who You Want to Be (Boulder, CO: Real People Press, 2002), 41. 
lebar ketika istilah di atas, ia justru memilih tidak menggunakan ketiganya. Yang ia usulkan, sekaligus sebagai pendekatakannya dalam pembahasan tentang 'diri' adalah 'konsep diri' (selfconcept). Ia mengandaikan konsep diri manusia seperti sebuah peta tentang siapa manusia sebenarnya. ${ }^{11}$ Karena menurutnya, sebuah teritori dapat dengan mudah dijelalahi atau dikenali melalui peta itu. Jalan, gedung, gang, marka-marka jalan, dan sebagainya tercetak rapi dan berwarna dalam sebuah peta. Ia akan membawa pencari alamat ke tujuan yang tepat. Walaupun demikian, perbedaan tetap terlihat dengan jelas. Sebuah peta yang dicetak pada tahun 1970-an akan sangat berbeda dengan peta tahun 2019. Artinya mengandaikan konsep diri seperti sejenis peta yang mengarahkan orang lain pada arah penilaian diri baik diri sendiri maupun orang lain kurang tepat.

Seorang psikolog yang dahulu dipengaruhi oleh Freud, Karen Horney $^{12}$ mengusulkan 4 (empat) gambaran diri, yakni: despised real self, real self, ideal self, dan actual self. Dari empat itu, 3 (tiga) konsep pertama adalah subjektif, dan satu objektif. Tiga pandangan tentang subjektif adalah diri rendah, diri yang sebenarnya, dan diri yang seharusnya; sedangkan yang satu adalah konsep diri yang apa adanya. Horney sendiri lebih menekankan konsep reealisasi diri. Namun, soal konsep realisasi diri, ada juga psikolog terkenal yang bernama Carl Jung (1875).

11 Andreas, Transforming, 43.

12 Ia, bersama Adler, dan Rank telah menyimpang dari Freudianisme ortodoks (lih.
Sebagaimana dijelaskan oleh Vitz, ${ }^{13}$ tujuan realisasi diri atau aktualisasi diri berciri gnostik yang telah menggeser (baca: menggantikan) perintah: "Kasihilah TUHAN Allahmu dan kasihilah sesamamu manusia". Yang menjadi tujuan dari realisasi diri adalah kenalilah dan ekspresikan diri Anda. Bahaya dari pandangan ini adalah penggeseran nilai-nilai spiritualitas atau tepatnya iman kekristenan.

Di dunia pendidikan, teori diri dikaitkan dengan model pendidikan moral. Dari sana dikembangkan sebuah pendekatakan khusus yang dikenal dengan nama Klarifikasi Nilai-nilai. Penggagasnya adalah Louis E. Raths dan Sidney B. Simon. Sasaran dari model pendekatan ini adalah keberanian anak-anak mengambil keputusan secara mandiri dan bertanggungjawab. Baik Raths maupun Simon, keduanya menolak semua upaya pendidikan nilai yang diajarkan oleh orang tua atau gereja secara langsung kepada anak-anak. Karena bagi mereka hal itu adalah sebuah bentuk pemaksaan nilai-nilai yang dianut oleh orang dewasa dan sudah kuno. Sedapat mungkin seorang anak diberikan ruang lebih luas dan leluasa untuk berproses sampai akhirnya ia dapat mengambil keputusan secara mandiri dan sadar akan konsekuensi. Proses diri yang dimaksud adalah proses menilai. Pada proses tersebut terdapat 3 (tiga) faktor mendasar: memilih, menghargai, dan bertindak. $^{14}$

Paul C. Vitz, Psikologi sebagai Agama, 2).

${ }^{13}$ Vitz, Psikologi, 101.

14 Ibid. 
POTENSI

Secara etimologis, kata benda potensi diturunkan dari kata Latin potent atau potentem (abad $15 \mathrm{M}$ awal), yang berarti 'being powerful/able' atau 'powerful' (sangat kuat, berpengaruh). Dalam bahasa Indonesia, kita dapat memahaminya sebagai kemampuan yang mempunyai kemungkinan untuk dikembangkan, kekuatan, atau kesanggupan, dan daya.

Pengertian di atas kemudian diperluas ke berbagai bidang. Salah satunya adalah psikologi. Narvaez, misalnya, mengaitkannya dengan kapabilitas diri, walaupun konsep ini berkembang dalam konteks ekonomi dan filsafat. ${ }^{15}$ Menurut Martha C. Nussbaum, kapabilitas adalah apa yang seseorang mampu lakukan dan menjadi apa di kemudian hari. Menrutnya, sebagaimana diyakini oleh Narvaez, kapabilitas berkaitan juga dengan politik, salah dari 10 (sepuluh) yang berperan sentral dalam hal kapabilitas. ${ }^{16}$ Kapabilitas terlihat sebagai sebuah kebebasan yang substansial untuk mencapai suatu target. Charles T. Tart mengemukakan pengertian kapabilitas dalam konsep potensi dalam dua kata yang mengandung gagasan nyaris sama. Pertama, kapasitas-kapasitas dalam hubungannya dengan potensi. Mungkin sekarang, beberapa dari 'kapasistas' itu masih potensial berkembang dengan sejumlah syarat-syarat tertentu yang

15 Darcia Narvaez, "Basic Needs and Fulfilling Human Potentia", dalam Basic Needs, Wellbeing and Morality. Fullfiling Human Potental, ed. Darcia Narvaest (Switzerland, AG: Palgrave MacMillan, 2018), 146. ikut mendorong tindakan nyata sebagai perwujudannya. Kedua, posibilitas manusia yang tidak tercerahkan. Dengan pencerahan, posibilitas manusia seharusnya tidak jatuh terjerembab, sehingga ia tidak bisa bangkit kembali. Apapun jenis faktor eksternal yang menjadi rintangan bagi posibilitas itu terwujud, seharusnya tidak menyeret kepada kesuraman diri yang berkepanjangan. ${ }^{17}$

Selain Narvaez, Nussbaum, Shawn Achor dalam bukunya "Big Potential" pada akhirnya memahami potensi sebagai sebuah interkoneksi (keterhubungan satu dengan yang lain). Ia mencontohkan Thomas Alva Edison yang memiliki 1900 hak paten. Tidak seorang pun yang dapat meragukan kejeniusan Edison. Namun, Edison tidak bekerja sendiri. Dalam kejeniusannya ia terhubung dengan orang lain, yaitu tim inventor-nya. Karena itu menurut Achor "bahkan seorang jenius pun terkoneksi dengan yang lainnya" termasuk orang-orang yang tergolong kurang jenius seperti Thomas A. Edison. Di mata Achor, Edison sebagai contoh yang bagus tentang apa yang bisa kita gapai ketika mengakui bahwa potensi itu sebenarnya sebenarnya terkonteksi dengan orang lain. Banyak orang yang membantu Edison sehingga ia bisa disebut penemu yang hebat dan berpengaruh di sepanjang masa karena bantuan timnya. Ia menjadi lebih

${ }^{16}$ Narvaez, "Basic Needs", 146.

17 Charles T. Tart, Waking Up. Overcoming the Obstacles to Human Potential (Lincoln, NE: An Authors Guild Backinprint.com, 2001), 16. 
kreatif, dan yang terpenting adalah bahwa ia masuk ke dalam sebuah ekosistem yang penuh daya dan karya. ${ }^{18}$ Itulah yang dinamakan potensi besar. Gagasan yang hendak ditekankan oleh Achor adalah pemahaman bahwa potensi besar, kejeniusan, kreatifitas, dan inspirasi, bukan seseuatu yang Anda dan saya miliki. Ia menambahkan "it is something you tap into." Bersama tim risetnya, Achor kemudian menyimpulkan bahwa "Potensimu adalah sebuah jalan yang lebih besar dari dirimu sendiri". ${ }^{19}$

Ada satu kutipan yang dibuat oleh Carol S. Dweck terhadap pemikiran Howard Gartner dalam bukunya "Extraordinary Minds" terhadap individu-individu yang luar biasa (exceptional individuals). Gartnersebagaimana dikutip oleh Dweckmengatakan: "exceptional individuals have a special talent for identifying their own strengths and weaknesses. It's interesting that those with the growth mindset seem to have that talent." 20 Hal yang dimaksud oleh Gartner dan juga yang jadi penekanan Dweck adalah soal talenta. Dweck bahkan melanjutkan "The other thing exceptional people seem to have is a special talent for converting life's setbacks into future successes." Talenta itu dianggap memiliki potensi untuk mengubah kemunduran hidup ke dalam keberhasilan di masa

18 Shawn Achor, Big Potential. How Transforming the Pursuit of Success Raises Our Achievement, Happiness, and Well-Being (New York: Currency, 2018), 55.

${ }^{19}$ Achor, Potential, 62

20 Carol S. Dweck, Mindset. Changing the Way You Think to Fulfil Your Potential (London: Robinson, 2017), 37. mendatang.

Dalam konteks pendidikan, Ken Richardson melihat bahwa potensi yang berkembang melalui pembelajaran di sekolah dapat dilihat menyerupai sebuah proses evolusi Darwin di mana proses seleksi alamiah terjadi. Yang memiliki potensi yang lebih kuat terseleksi dari yang lemah. Instrumen yang ikut berperan adalah kurikulum. Semua bentuk ujian yang diberikan di sekolah menjadi lebih penting ketimbang pengaruh keluarga. ${ }^{21}$

Penelurusan yang dilakukan oleh Richardson memang menyinggung soal faktor genetis (baca: gen keluarga), IQ, dan ras $^{22}$ (baca: pengelompokkan manusia). Apakah pengaruh-pengaruh genetis, tingkat kecerdasan, dan ras dapat memotret tingkat potensi seseorang? Tidak seluruhnya benar bahwa ketiganya mutlak menjadi gambaran potensi manusia. Misalnya, soal IQ. Alih-alih tetap berpegang pada kecerdasan secara intelektual, perkembangan selanjutnya justru mengejutkan karena ternyata emosi juga dapat dilihat sebagai sebuah kecerdasan yang patut dipertimbangkan dan diperhitungkan. Itulah sebabnya muncul kemudian rumusan EQ. Belum lagi euforia EQ itu berlalu, kecerdasan sudah meluas ke ranah kecerdasan spiritualitas, yakni SQ. Baik IQ, EQ, maupun SQ semuanya

21 Ken Richardson, The Origin of Human Potential. Evolution, Development, and Psychology (London: Routledge, 1998), 188.

22 Bukan dalam pengertian isu yang memicu konflik sosial. 
merupakan kecerdasan hakiki dari manusia, bukan artifisial sebagaimana sekarang menjadi trend dengan istilah Artificial Intelligence (AI), yang notabene hanya merepresentasi kecerdasan intelektual (IQ). AI sama sekali tidak memiliki emosi, apalagi spiritualitas. Kecerdasannya adalah kecerdasan mesin dan bersifat digital atau computerised.

\section{Perspektif Alkitab}

Melihat (dan memahami) manusia dari sudut pandang Alkitab, tidak sama dengan cara pandang psikologi, sosiologi, dan filsafat. Alkitab (baca: teologi) melihat manusia sebagai makhluk ciptaan yang utuh, yang terdiri atas tubuh dan jiwa/roh. ${ }^{23}$ Manusia adalah satu-satunya makhluk yang diciptakan dengan sebuah keputusan ilahi yang luar biasa: baiklah Kita menciptakan manusia menurut gambar-rupa Kita. Ia adalah ciptaan yang mewarisi, tetapi juga sekaligus tidak mewarisi apa yang ada pada TUHAN. Dikatakan 'mewarisi' karena ia adalah makhluk yang mampu mewujudnyatakan cintakasih, keadilan, kejujuran, kekudusan, dan lain sebagainya. Namun, di saat bersamaan (tanpa adanya jeda), ia tidak bisa dikatakan makhluk yang maha adil, maha kudus, dan maha hadir. Ia tidak mewarisi itu dari TUHAN. Ia punya kemampuan skill dan atau potensi (kuasa, pengaruh, dst.). Tetapi itu tidak membuatnya untuk mengingkari

23 Dalam diskursus tentang antropologi terdapat 2 (dua) pendekatan: dikotomi atau trikotomi.

${ }^{24}$ Anthony A. Hoekema, Manusia: Ciptaan Menurut Gambar Allah, terj. Irwan Tjulianto (Surabaya: Momentum, 2003), 7. naturnya sebagai ciptaan, bukan Pencipta. Karena itu ia tetap akan terlihat sangat terbatas. Sebagai ciptaan Allah, manusia tidak bereksistensi secara otonom atau independen. ${ }^{24}$

Soal-soal yang belakangan muncul secara detail, dan sampai menimbulkan perdebatan panjang tentang diri dan potensinya-apa dan bagaimana keduanya dipahami-adalah dampak dari pembahasan yang detail tersebut. ${ }^{25}$ Artinya, Alkitab hanya menyebutkan bahwa manusia adalah pribadi yang utuh. Atau mengutip pandangan Sihotang, "Manusia menjadi pribadi atau individu karena jiwa dan badannya bersatu. Ia adalah jiwa yang berbadan (atau: bertubuh), dan badan (tubuh) yang berjiwa." 26

Sekali lagi akan diulangi di sini bahwa Alkitab tidak bermaksud memberikan peluang sedemikian luasnya untuk mempersoalkan siapa sebenarnya manusia itu. Bahwa psikologi, sosiologi, filsafat, dan bahkan teologi dari perspektif ilmu pengetahuan mendiskursuskannya adalah soal tersendiri. Semua diskursus yang lahir dari disiplin ilmu di atas secara sederhana telah mengungkap fakta bahwa manusia bukanlah ciptaan yang hanya terdiri atas unsur bendawi (tubuh) saja, melainkan juga unsur jiwa/roh. Dari sudut pandang psikologi, yang menjadi perhatian adalah emosi dan afeksi. Rene Descartes membuka pemahaman

${ }^{25}$ Lihat lagi sub judul tentang Diri dan Potensi pada paragraf sebelumnya.

${ }^{26}$ Kasdin Sihotang, Filsafat Manusia: Jendela Menyingkap Humanisme (Yogyakarta: Kanisius, 2018), 41. 
psikologi melalui ungkapan tertulisnya Cogito ergo sum (saya berpikir maka saya ada). Sihotang menengarai bahwa konsep persona menurut Descartes diletakkan pada animus (atau jiwa). ${ }^{27}$

Manusia juga adalah ciptaan yang dapat berelasi dengan baik dengan makhluk lain (secara sosiologis). Berelasi dalam arti socius (menjadi sahabat). ${ }^{28}$ Ia mampu membangun peradaban masyarakat dalam konteks yang berbeda. Misalnya, kebudayaan, bahasa, dan suku. 'Masyarakat' adalah salah satu indikator yang kuat yang dapat dijadikan sebagai wujud sosialitas manusia.

Dari perspektif fislafat, pencarian jati diri manusia tertuju pada pengakuan bahwa ia adalah ciptaan yang berhikmat/bijaksana. Ia bukan sekadar makhluk ontologis (ber-ada). Kesadaran keber-ada-nya bukan saja melibatkan 'diri-aku', diri-engkau', tetapi juga 'diri-dia'. Bahkan lebih dari itu, bukan sekadar adanya keterkaitan 'diri-di sini', namun juga 'diri-di sana'. Relasi ke dalam dan ke luar, dalam ruang dan waktu yang berbeda lahir dari sebuah pemikiran kritis dan berhikmat. Manusia mampu melihat dirinya sebagai makhluk 'metafisis' (tak hanya terikat pada unsur tubuh/bendawi). Di sinilah kemampuan manusia secara filosofis tampak begitu mengagumkan.

Lebih dari itu, manusia adalah

${ }^{27}$ Ibid.

${ }^{28}$ Adelbert Snijders, Antropologi Filsafat: Manusia, Paradoks, dan Seruan (Yogyakarta: Kanisius, 2004), 50. ciptaan yang memiliki relasi dengan TUHAN. Relasi itu tidak didasarkan pada naluri atau insting, seperti halnya pada hewan atau binatang, melainkan pada kesadaran penuh bahwa ia adalah ciptaan yang segambar-serupa dengan Allah. Pemaknaan relasi di atas lebih bersifat teologis, dari pada mendasarkannya pada aspek psikologis, sosiologis, dan filosofis. Glen G. Scorgie tidak serta merta melihat bahwa penciptaan manusia sebagai sebuah pembenaran bahwa TUHAN sangat memerlukan manusia. Keserupaan dan kesegambarannya dengan Allah mengambil bagian pada Allah Tritunggal yang berelasional. ${ }^{29}$ Karena itu menurut Scorgie, kita juga dirancang bagi sebuah relationship yang mulia dan dinamis. 30

Unsur rohani (spiritualitas) sangat krusial bagi manusia. Ia bukanlah sekadar sebuah label yang menunjuk pada keunikannya. ${ }^{31}$ Menurut Sihotang, dengan dimensi rohani ini, setiap manusia dapat menentukan pilihan yang berbeda, memiliki watak yang juga berbeda, serta menghasilkan pikiranpikiran yang mengagumkan. ${ }^{32}$ Dengan mengaitkan unsur rohani kepada penentuan pilihan dan dihasilkannya pikiran-pikiran yang mengagumkan, maka terlihat di sini ekspansi (perluasan) dari pengaruh spiritualitas manusia itu. Agak sulit mengurung (atau membatasi) spiritualitas pada diri

${ }^{29}$ Glen G. Scorgie, A Little Guide to Christian Spirituality. Three Dimensions of Life with God (Grand Rapids, MI: Zondervan, 2007), 41.

${ }^{30}$ Ibid.

${ }^{31}$ Kasdin Sihotang, Filsafat Manusia, 41,45.

${ }^{32}$ Ibid. 
manusia, seperti seolah-olah ada periode tertentu di mana spiritualitas itu timbul dan tenggelam. Tetapi, tidak bisa juga dianggap keliru jika kerohanian manusia bermasalah, bila terjadi pemberontakan yang serius dari manusia terhadap Penciptanya.

Jika demikian halnya, benarkah apa yang dikatakan oleh Tart bahwa "In spiritual language, we have lost the power, reality, and purity of our full nature; we have gone through some kind of Fall from grace, so we live life in a narrow, constricted, unhappy way?"33

Dengan kehidupan spiritualitas yang sehat dan benar, memungkinkan bagi seseorang untuk mengenal dirinya dengan baik dan benar juga. Karena spiritualitas yang sehat, juga benar itu, bertolak dari Allah sebagai Pencipta. Ini akan membawanya kepada pengenalan akan Allah yang benar. Lalu pengenalan itu berdampak bagi pengenalan diri manusia secara benar juga. Itu juga berarti bahwa segala potensinya akan tampak dengan jelas dalam terang pengenalan akan Allah dan pengenalan akan diri sendiri.

Dalam konteks manakah tujuan pengembangan potensi diri digambarkan dalam Alkitab? Atau lebih tepatnya, dalam orientasi apakah tuntutan pengembangan potensi diri dilakukan? Secara implisit sudah disebut di atas bahwa 'manusia' sebagai ciptaan Allah telah menegasikan pola hidup selfish (mementingkan diri sendiri), melainkan hidup berelasi, baik dengan TUHAN maupun dengan sesamanya. Artinya, pengembangan diri dan potensinya adalah perwujudan dari kasih kepada TUHAN. Kasih itu akan menempatkan TUHAN sebagai yang pertama, lalu sesama manusia (orang lain, siapapun dia), dan yang terakhir adalah diri sendiri. Inilah ordo (urutuan) pemahaman diri manusia. Benarlah perkataan rasuli berikut ini: "Sebab tidak ada seorang pun di antara kita yang hidup untuk dirinya sendiri, dan tidak ada seorang pun yang mati untuk dirinya sendiri" (Rm. 14:7). Dengan kata lain, selama ia hidup, yang menjadi tujuan bukanlah keuntungan/kepentingan diri sendiri, melainkan orang lain juga (1 Kor. 10:24). Bahwa manusia lebih mencintai diri sendiri adalah suatu fakta yang tidak bisa disangkali (lih. 2 Tim. 3:2).

Potensi diri adalah gift (pemberian). Keberadaan potensi diri pada manusia tidak secara eksplisit disebutkan di dalam Alkitab. Namun, secara implisit hal itu dapat ditelusuri di dalamnya. Bila pengertian potensi sebagaimana disebutkan di atas, yakni: capablity dan capacity, di luar possibility, maka yang dimaksud adalah kemampuan atau skill. Bahwa seseorang memiliki kemampuan atau keahlian yang menunjukkan kapabilitas dan kapasitasnya di mata orang lain adalah benar. Tetapi, kemampuan atau keahlian itu bersifat well trained (terlatih dengan baik). Alih-alih demikian, soal keahlian dan kemampuan di dalam Alkitab justru dianggap sebuah gift (pemberian) dari Allah. Dalam narasi Eksodus (Kel. 28:3; 31:3,6; 35:26; $35: 31,35 ; \quad 36: 1,2)$, orang yang 
bertanggungjawab

terhadap

pekerjaan/pelayanan adalah yang

dipenuhi dengan keahlian dan pengetahuan. Bahkan keahlian dan pengetahuan itu berasal dari (karunia) TUHAN.

Pengembangan potensi diri adalah kepercayaan (trust). Misalnya, ketika Alkitab menggambarkan perumpamaan tentang seseorang yang menerima 1 sampai 5 talenta (Yun. talanton). Dari gambaran itu dapat dipahami bahwa potensi seseorang itu bersifat proporsional. Kemampuannya dalam mengola 1 menjadi 2, 2 menjadi 4, 5 menjadi 10 adalah sebuah keniscayaan yang tidak bisa dinafikan begitu saja. Yang menjadi krusial di sini adalah cara memandang kepercayaan itu. Apakah dengan diberikan $1,2,5$, dengan sendirinya mengurangi potensi diri? Tentu tidak. Kesadaran diri akan potensi yang dimilikinya menjadi lebih penting dan prioritas, daripada memikirkan daftar jumlah potensi yang ia impikan. Sebab 1 (satu) potensi lebih bermakna dari pada 99 potensi yang tidak ada pada dirinya!

Dalam kapasitas sebagai seorang sarjana Kristen, kita menerima dua kepercayaan sekaligus. Pertama, dari TUHAN dan kedua, dari lembaga atau institusi di mana kita melayani dan mengabdi. Kedua-duanya memerlukan pertanggungjawaban yang seyogyianya melampaui standar dalam bentuk kinerja pelayanan/pekerjaan kita.

Pengembangan potensi diri adalah sebuah usaha (effort). Menyadari bahwa kepada setiap orang diberikan (gift) dan dipercayakan (trusted) potensi diri, maka kemampuan untuk melakukannya akan berbanding lurus dengan potensi itu. Potensi diri memang berpeluang didiamkan atau tidak dikembangkan. Namun, bila potensi diri tersebut (berapa pun potensinya), dikembangkan dengan baik dan bertanggungjawab, maka hasilnya pun akan terlihat sama. Satu menghasilkan satu, dan seterusnya.

Pengembangan potensi adalah aktualisasi nilai diri (values). Nilai diri sebagai ciptaan baru (2 Kor. 5:17) lebih dari sekadar self-esteem (harga diri; penghargaan diri). Apa yang hendak dicapai dari pengembangan (potensi) diri tidak lain ada ekspresi nilai-nilai kehidupan. Pencapaian itu bukan sebuah pengejaran harga diri, melainkan sebuah bentuk pertanggungjawaban (responsibility) orang Kristen terhadap gift dan trust dari TUHAN. Yang perlu diantisipasi di sini adalah faktor internal dan eksternal. Sebagai filter (penyaring) yang berperan penting untuk mengantisipasi penilaian terhadap pengembangan diri itu adalah kematangan atau kedewasaan (maturitas) seseorang. Idealnya, semakin dewasa seseorang (dalam pemikiran dan perilaku), maka semakin mampu ia merendahkan hatinya. Sebagai seorang sarjana Kristen, berkenosis (merendahkan diri) seperti yang dilakukan oleh Yesus Kristus patut menjadi penyemangat dan sekaligus filosofi dalam pekerjaan dan pelayanan kita.

Keempat hal di atas: gift, trust (atau keduanya bisa dijadikan satu: gift-trust), effort, dan value merupakan prinsip utama dalam pemahaman pengembangan potensi diri. 
Keempatnya juga adalah mata rantai pengembangan potensi diri yang saling terhubung.

\section{PENUTUP}

Mengembangkan potensi diri tidak bertolak dari masa lampau. Pengembangan diri itu lebih bersifat present dan future. Dengan kata lain: kontekstual dan antisipatif. Siapapun yang berkomitmen untuk mengembangkan potensi dirinya, tidak lagi berurusan dengan dirinya. Karena seharusnya diri sendiri sudah bukan menjadi soal yang menarik dan menghabiskan energi dan perhatian.

Isu yang menarik dalam pengembangan potensi diri adalah kesiapan diri. Hitung dengan cermat dan bijaksana. Melarikan diri dari tantangan pelayanan/kerja dan zaman bukanlah gambaran sarjana Kristen yang dibesarkan dalam disiplin ilmu teologi. Karena teknologi adalah soal skill, bukan soal karakter. Ia akan dengan mudah bisa ditaklukkan. Skill (keahlian di bidang teknologi, misalnya) bisa dengan mudah dipelajari. Tetapi soal karakter, KEPUSTAKAAN integritas, tanggung jawab, kejujuran, moral, etika, dan kerohanian (spiritualitas), hal-hal ini menjadi motor penggerak yang mendorong setiap orang Kristen yang mencintai kebenaran dan mengasihi TUHAN, terus mengembangkan diri dalam pekerjaan dan pelayanan!

Kutipan dari tulisan Myles Munroe berikut ini penting untuk dihayati: "Potensi adalah kemampuan yang tidak aktif, kekuatan cadangan, kekuatan yang belum dimanfaatkan, keberhasilan yang belum dipakai, telenta tersembunyi, kemampuan yang masih tertutup. Semua yang dapat Anda capai namun belum terwujud, semua yang Anda mampu lakukan namun belum dilaksanakan, sejauh yang dapat kita capai namun belum tercapai, apa yang dapat kita selesaiakan namun belum diselesaikan. Potensi adalah kemampuan yang belum tersingkap dan kekuatan yang terpendam. Karena itu potensi bukan apa yang telah kita lakukan, melainkan apa yang kita sanggup lakukan. Potensi tidak pernah mempunyai rencana pensiun." 34 Potensi tidak akan pernah berhenti pada titik keberhasilan.

\section{Buku}

Achor, Shawn. Big Potential. How Transforming the Pursuit of Success Raises Our Achievement, Happiness, and Well-Being. New York: Currency, 2018.

Andreas, Steve. Transforming Your Self: Becoming Who You Want to Be. Boulder, CO: Real People Press, 2002.

Bandura, Albert. Self Efficacy. The Exercise of Control. New York: W.H. Freeman and Company, 1997.

\footnotetext{
${ }^{34}$ Myles Munroe, Menemukan Diri Anda yang Tersembunyi, terj. L.I.S. (Jakarta: Immanuel Publishing House, 2007), 19-20
} 
Dweck, Carol S. Mindset. Changing the Way You Think to Fulfil Your Potential. London: Robinson, 2017.

Hoekema, Anthony A. Manusia: Ciptaan Menurut Gambar Allah, terj. Irwan Tjulianto. Surabaya: Momentum, 2003.

May, Rollo. Existence. New York: Basic Books, 1958.

Munroe, Myles. Menemukan Diri Anda yang Tersembunyi, terj. L.I.S. Jakarta: Immanuel Publishing House, 2007.

Narvaez, Darcia. "Basic Needs and Fulfilling Human Potentia", dalam Basic Needs, Wellbeing and Morality. Fullfiling Human Potental, ed. Darcia Narvaest.

Switzerland, AG: Palgrave MacMillan, 2018.

Richardson, Ken. The Origin of Human Potential. Evolution, Development, and Psychology. London: Routledge, 1998.

Rustika, I Made. "Efikasi Diri: Tinjauan Teori Albert Bandura" dalam Buletin Psikologi, vol. 20, No.1-2, 2012.

Scorgie, Glen G. A Little Guide to Christian Spirituality. Three Dimensions of Life with God. Grand Rapids, MI: Zondervan, 2007.

Sihotang, Kasdin. Filsafat Manusia: Jendela Menyingkap Humanisme. Yogyakarta: Kanisius, 2018.

Snijders, Adelbert. Antropologi Filsafat: Manusia, Paradoks, dan Seruan. Yogyakarta: Kanisius, 2004.

Tart, Charles T. Waking Up. Overcoming the Obstacles to Human Potential. Lincoln, NE: An Authors Guild Backinprint.com, 2001.

Vitz, Paul C. Psikologi sebagai Agama: Kultus Penyembahan Diri, terj. Yulvita Hadiyarti. Surabaya: Penerbit Momentum, 2005.

Wittgenstein, Ludwig. Tractatus Logico Philosophicus, ${ }^{2}$ terj. D.F. Pears dan B.F. MacGuinnes. London/New York: Roudledge, 1974.

\section{Link}

https://inet.detik.com/consumer/d-4192214/untuk-apa-saja-dana-riset-miliaran-dolarhuawei/komentar?device $=$ desktop

\section{Alkitab}

Lembaga Alkitab Indonesia Terjemahan Baru (LAI-TB1), 1974. 